\title{
Wheat Stem Rust Race Ug99: A Shifting Enemy
}

\author{
Ambika Rautela* and Meenakshi Dwivedi
}

Gobind Ballabh Pant University of Agriculture and Technology, Pantnagar, Udham Singh Nagar, Uttarakhand-263145, India

*Corresponding author

\section{A B S T R A C T}

\begin{tabular}{|c|}
\hline Keywords \\
\hline $\begin{array}{l}\text { Wheat, Black stem } \\
\text { rust, Ug99 }\end{array}$ \\
\hline Article Info \\
\hline $\begin{array}{l}\text { Accepted: } \\
\text { 12 December } 2017 \\
\text { Available Online: } \\
\text { 10 January } 2018\end{array}$ \\
\hline
\end{tabular}

Since, time immemorial wheat stem rust has been one of the major threats to wheat cultivation all around the world. Owing to the alarming rate at which Puccinia graminis tritici, evolves and mutates, the popularly grown wheat varieties remain at constant stake of losing their resistance to it. Since, wheat is the second most important crop in the world, a constant threat hovers over the global food security too. To make situation worse, a novel race of stem rust pathogen, Ug99 has evolved, popularly known as 'shifting enemy of wheat' due to its rapid migration rate. Researchers have already anticipated Ug99 as the greatest of threats ever faced by wheat cultivation as it has the potential of breaking the strongest of resistant genes, like $S r 31$. Since, the race hasn't spread into many area, we still stand a chance of killing it in its crib. A plethora of initiatives and strategies have been taken globally, of which BGRI is the most prominent one. This horror has to be dealt with brotherhood among whole scientific fraternity and stringent regulatory measures from the governments together with immense trust of farmers on the system.

\section{Introduction}

Pressures on food security, across the globe are being made worse by plant diseases that are emerging more frequently and spreading very rapidly. This is a situation fuelled by climate change in increasingly fragile ecosystem. Our planet earth is currently experiencing dramatic change with predicted rates of global-mean temperature increase unprecedented in the past 1000 years (Santini and Ghelardini, 2015). Extreme climatic events are becoming more intense and very frequent. Such sudden changes in nature led to evolution of new plant pathogenic races which may near future, lead to serious epidemics.
These plant disease epidemics increase the price of food and pose a real threat to rural livelihoods and regional food security. Accounting for humanity's food, wheat is second only to rice as an important source of calories in the diet of developing country consumers. Wheat suffices for $21 \%$ of the food calories and $20 \%$ of the protein requirement to more than 4.5 billion people in 94 developing countries (Braun et al., 2010).

One such disease which poses a serious threat and challenge to wheat crop is black stem rust which has become an emerging problem due to rapid development of new races or variants of stem rust pathogen. 


\section{Stem Rust: Worst Enemy of Wheat}

Among all the wheat diseases, wheat stem rust, a calamitous disease caused by the fungus Puccinia graminis Pers. f. sp. tritici Eriks. and E. Henn. has been a major historical problem (Sari and Prescott, 1985). Stem rust is the polio of agriculture, a plague that was curbed nearly half a century ago as part of the celebrated Green Revolution. Stem rust can cause severe yield losses in susceptible cultivars of wheat in environments favourable for disease development (Leonard and Szabo, 2005). Wheat stem rust has largely been under control for over three decades due to the widespread use of resistant cultivars. The last wheat rust epidemic was seen in Ethiopia in 1993 and 1994 (Shank, 1994; Badebo, 2002) where a popular wheat variety 'Enkoy' suffered serious losses but rest of the world remain unhurt for over three decades from stem rust (Singh et al., 2008).

After years of consistent trial and error, scientists managed to breed wheat that contained genes capable of repelling the assaults of Puccinia graminis. But now it's clear that the triumph didn't last long and today's scenario of wheat rust is different from the past. Changing temperature and rainfall patterns have encouraged the emergence of new stem rust races that overcome the currently resistant wheat varieties.

One such example is the emergence of wheat stem rust race, Ug99. This is the only wheat stem rust race carrying broad virulence spectrum against many resistance genes including Sr31 and is called as 'Super Race' by many workers (Joshi et al., 2008). Emergence of race $\mathrm{Ug} 99$ is considered as highly significant issue which may have far reaching consequences on global wheat production, as majority of wheat varieties show susceptibility against this race. It has been estimated that the area under risk of Ug99 amounts to around 50 million ha of wheat grown globally i.e., about $25 \%$ of the world's wheat area (Singh et al., 2008). The race is expected to move in South Asia where wheat is one of the most important staple food crops for a large population. Therefore, stem rust has again become a major threat to global wheat production, in particular and food security, in general (Singh et al., 2011).

\section{Race UG99}

In the year 1998, wheat nurseries planted at CIMMYT in Uganda suffered from serious infection by wheat stem rust. This susceptibility of plants was quite surprising because the planting material was resistant to stem rust pathogen. When uredospore samples were collected for race analysis, presence of a new race with novel resistance was found against the resistance gene $\mathrm{Sr} 31$ (Pretorius et al., 2000).This new wheat stem rust race come to known popularly as Ug99 after the country and year of discovery. It was designated as TTKS by (Wanyera et al., 2006) using the North American nomenclature system (Roelfs and Martens, 1988) and more recently as TTKSK after addition of fifth set of differentials to further expand the characterization (Jin et al., 2008).

The East African highlands are a known "hotspot" for the evolution and survival of new rust races (Sari and Prescott, 1985). The pathogen is evolving rapidly and till date thirteen known variants within Ug99 lineage have been identified. The Ug99 race lineage is present in 13 countries, with Egypt being the most recent one. The latest variants are: TTKSF+ which was detected in South Africa and Zimbabwe (Pretorius et al., 2012), TTHST which was collected in Kenya in 2013; TTKTT, TTKTK. PTKTK and TTHSK (Patpour et al., 2015; Fetch and Zegeye, 2016) - all were collected from Kenya in 2014 


\section{Spread of Race UG99}

Riding the everlasting blowing winds, Ug99 and its variants has now breached the best defenses science can ever offer. It is acting as a shifting enemy. Its range is expanding continuously at a very high rate. Firstly it was reported from Uganda, later it was reported from eastern Kenya in 2001. The presence of Ug99 in Ethiopia was recorded in 2005 (Fig. $1)$.

In the year 2006 (February/ March) it was reported from eastern Sudan. Same year in the month of October- November reports confirming presence of Ug99 were obtained from western Yemen. In the year 2007, samples collected from two field sites in Iran also confirmed the presence of race Ug99
(Nazari et al., 2009). The observed expansion of Ug99 and its variant into new areas is inaccordance with previous predictions made on its likely movement (Hodson et al., 2005; Singh et al., 2006) and it fits the step-wise dispersal model following prevailing winds (Singh et al., 2008).

It has been predicted that the path of spread of Ug99 could follow the route taken by $Y r 9$ virulent pathotype of $P$. striiformis which, in the late 1980s was originated in Africa and later spread to the Arabian Peninsula, Syria, and finally eastward towards Pakistan and India (Singh et al., 2006). Similar trajectories from Ug99 sites in Iran indicate that Iran can be gateway for Ug99 migration to other Asian countries (Singh et al., 2008) (Table 1).

Table.1 Ug99 group of races identified until 2010 in various countries and their key virulence differences (Singh et al., 2011)

\begin{tabular}{|c|c|c|c|c|c|c|}
\hline \multirow[t]{2}{*}{ Race } & \multirow{2}{*}{$\begin{array}{l}\text { Common } \\
\text { alias }\end{array}$} & \multicolumn{4}{|c|}{ Key virulence difference } & \multirow[t]{2}{*}{ Confirmed Countries } \\
\hline & & Sr31 & Sr21 & Sr24 & Sr36 & \\
\hline TTKSK & Ug99 & Vir & Vir & Avir & Avir & $\begin{array}{l}\text { Uganda(1998), Kenya (2001), Ethiopia(2003), } \\
\text { Sudan(2006), Yemen(2006), Iran(2007) }\end{array}$ \\
\hline TTKSF & & Avir & Vir & Avir & Avir & SouthAfrica(2000), Zimbabwe(2009) \\
\hline TTKST & Ug99+Sr24 & Vir & Vir & Vir & Avir & Kenya(2006) \\
\hline TTTSK & Ug99+Sr36 & Vir & Vir & Avir & Vir & Kenya(2007) \\
\hline TTKSP & & Avir & Vir & Vir & Avir & South Africa (2007) \\
\hline PTKSK & & Vir & Avir & Avir & Avir & Kenya(2007), Ethiopia (2007) \\
\hline PTKST & & Vir & Avir & Vir & Avir & Kenya(2008), South Africa(2009) \\
\hline
\end{tabular}

Fig.1 Current status and distribution of the Ug99 group of races

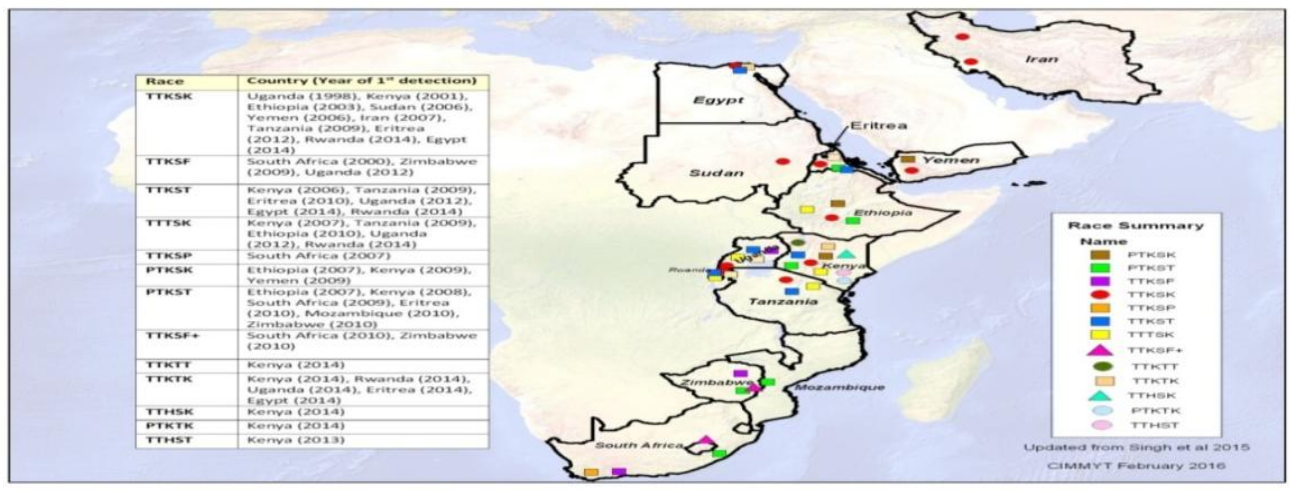




\section{Initiatives Taken by India to Combat UG99 Threat}

The importance of race Ug99 came into existence when Nobel Laureate Dr. Norman E. Borlaug raised awareness against threat possessed by Ug99 to world's food security. In response to Ug99's threat, the Borlaug Global Rust Initiative (BGRI), (earlier Global Rust Initiative) was established on 9 September 2005 at Nairobi, Kenya under the leadership of the late Nobel Peace prize winner, Dr Norman Borlaug. The important goal of the BGRI was to facilitate collaboration among the global community of wheat and rust researchers and to develop strategies on how to manage this serious disease.

It has been predicted that most of the area under world wheat production may suffer from serious epidemics and losses due to favourable environmental conditions for spread and outbreak of stem rust races. Also, there is less availability of resistant wheat cultivars and germplasm against Ug99 pathotypes. Detection of Ug99 in Egypt is of utmost importance because it provides indication that Ug99 may move towards Wheat growing areas of Middle East and South Asia. Indian wheat program is in collaboration with CIMMYT to identify various resistant cultivars and their deployment in different wheat zone before arrival of Ug99. A set of 19 Indian wheat varieties and 3 genetic stocks were screened under natural outbreak of Ug99 at Njoro (Nakuru), Kenya in the summer nursery 2005 (Joshi et al., 2008). So far Ug99 pathotypes have not been reported from India and Pakistan. Stem rust-prone areas in India are limited (about 25\% of total area) (Prasad et al., 2016). Hence, it may not be a threat in the main wheat belt (Nagarajan, 2012), yet we have to be vigil and prepared in case these pathotypes gain entry into the country.
Global agricultural fraternity has been shaken up by the emerging threat to the wheat's production posed by a race of Puccinia graminis tritici (black stem rust pathogen). $\mathrm{Ug} 99$ as the race is called, has been reported from Uganda in 1999 and has broken down Sr31 gene which is responsible for offering resistance against this rust in most of the popular varieties grown globally making all of them susceptible. Owing to the immense variability possessed by the race, it is one of the greatest fears confronted so far to the global wheat production. About $25 \%$ of the world wheat production area is anticipated to be at risk. So, stringent measures are immediately called for to curb this threat from going berserk. Though a herculean task, but synchronization among different agricultural disciplines and appropriate support from the government as well as legal system might work wonders in controlling this race from taking up form of an epidemic.

\section{References}

Badebo, A., 2002. Breeding bread wheat with multiple disease resistance and high yielding for the Ethiopian highlands: Broadening the genetic base of yellow rust and tan spot resistance. Ph.D. Thesis, Georg-August University of Goettingen, Germany $115 \mathrm{pp}$.

Braun H.J., Atlin, G. and Payne, T. 2010. Multilocation testing as a tool to identify plant response to global climate change. In: Climate Change and Crop Production (Ed. MP Reynolds), CABI London, UK, pp 115138.

Fetch, T. and Zegeye, T. 2016. Detection of wheat stem rust races TTHSK and PTKTK in the Ug99 race group in Kenya in 2014. Plant Dis 100:1495.

Hodson, D.P., Singh, R.P. and Dixon, J.M. 2005. An initial assessment of the potential impact of stem rust (race Ug99) on wheat producing regions of Africa and Asia using GIS. In: Abstracts of the 7th International Wheat Conference, Mar del Plata, Argentina, 142 pp.

Jin, Y., Pretorius, Z.A., Singh, R.P. and Fetch, T. 2008. Detection of virulence to resistance gene Sr24 within race TTKS of Puccinia 
graminis f. sp. tritici. Plant Dis 92: 923-926.

Joshi, A.K., Mishra, B., Prashar, M., Tomar, S.M.S. and Singh, R.P. 2008. Ug99 race of stem rust pathogen: Challenges and current status of research to sustain wheat production in India. Indian J Genet 68: 231-241.

Leonard, K.J. and Szabo, L.J. 2005. Stem rust of small grains and grasses caused by Puccinia graminis. Mol Plant Pathol 6: 99-111.

Nagarajan, S., 2012. Is Puccinia graminis f. sp. tritici- virulence Ug99 a threat to wheat production in the north west plain zone of India? Indian Phytopath 65: 219-226.

Nazari, K., Mafi, M., Yahyaoui, A. and Park, R.P. 2009. Detection of wheat stem rust (Puccinia graminis f. sp. tritici) race TTKSK (Ug99). Iran Plant Dis 93: 317.

Patpour, M., Hovmoller, M.S. and Justesen, A.F. 2015. Emergence of virulence to SrTmp in the Ug99 race group of wheat stem rust, Puccinia graminis f. sp. tritici, in Africa. Plant Dis 100: 522.

Prasad, P., Bhardwaj, S.C., Khan, H., Gangwar, O.P., Kumar, S. and Singh, S.B. 2016. Ug99: Saga, reality and status. Curr Sci 110:161416.

Pretorius, Z.A., Singh, R.P., Wagoire, W.W. and Payne, T.S. 2000. Detection of virulence to wheat stem rust resistance gene $\mathrm{Sr} 31$ in Puccinia graminis f. sp. tritici in Uganda. Plant Dis 84:203.

Pretorius, Z.A., Szabo, L.J., Boshoff, W.H.P., Herselman, L. and Visser, B. 2012. First report of a new TTKSF race of wheat stem rust (Puccinia graminis f. sp. tritici) in South Africa and Zimbabwe. Plant Dis 96:590.

Roelfs, A.P. and Martens, J.W. 1988. An international system of nomenclature for Puccinia graminis f. sp. tritici. Phytopathol 78: 526-33.
Saari, E.E., and Prescott, J.M. 1985. World distribution in relation to economic losses. In: The cereal rust. Volume II; Diseases, Distribution, Epidemiology, and control (Eds. Roelfs AP, Bushnell WR), Academia Press, Orlando. pp. 259-98.

Santini, A. and Ghelardini, L. 2015. Plant pathogen evolution and climate change. In: $C A B$ Reviews: Perspectives in Agriculture, Veterinary Science, Nutrition and Natural Resources.

Shank, R., 1994. Wheat stem rust and drought effects on bale agricultural production and future prospects. Report on February 17-28 assessment. In: United Nations Emergencies Unit for Ethiopia. Addis Ababa, Ethiopia.

Singh, R.P., David, P.H., Huerta-Espino, J., Jin, Y., Bhavani, S., Njau, P., Herrera-Foessel, S., Singh, P.K., Singh, S. and Govindan, V. 2011. The Emergence of Ug99 Races of the Stem Rust Fungus is a Threat to World Wheat Production. Ann Rev Phytopath 49: 465-481.

Singh, R.P., Hodson, D.P., Huerta-Espino, J., Yue, J., Njau, P., Wanyera, R., Herrera-Foessel, S.A. and Ward, R.W. 2008. Will stem rust destroy the world wheat crop. Adv in Agron 98: 271-309.

Singh, R.P., Hodson, D.P., Jin, Y., Huerta-Espino, J. and Kinyua, M. 2006. Current status, likely migration and strategies tomitigate the threat to wheat production from race Ug99 (TTKS) of stem rust pathogen. In CAB Reviews: Perspectives in Agriculture, Veterinary Science, Nutrition and Natural Resources, 1(54):1-13,

Wanyera, R., Kinyua, M.G., Jin, Y. and Singh, R.P. 2006. The spread of stem rust caused by Puccinia graminis f. sp. tritici, with virulence on Sr31 in wheat in Eastern Africa. Plant Dis 90:113.

\section{How to cite this article:}

Ambika Rautela and Meenakshi Dwivedi. 2018. Wheat Stem Rust Race Ug99: A Shifting Enemy. Int.J.Curr.Microbiol.App.Sci. 7(01): 1262-1266.

doi: https://doi.org/10.20546/ijcmas.2018.701.153 